\title{
Collapsin-1/Semaphorin-III/D Is Regulated Developmentally in Purkinje Cells and Collapses Pontocerebellar Mossy Fiber Neuronal Growth Cones
}

\author{
Sylvia A. Rabacchi,, ${ }^{1}$ Joanna M. Solowska, ${ }^{1}$ Barbara Kruk, ${ }^{1}$ Yuling Luo, ${ }^{2}$ Jonathan A. Raper, ${ }^{2}$ and \\ Douglas H. Baird 1 \\ 1Department of Neurobiology and Anatomy, MCP Hahnemann School of Medicine, MCP Hahnemann University, \\ Philadelphia, Pennsylvania 19129, and 2Department of Neuroscience, University of Pennsylvania School of Medicine, \\ Philade/phia, Pennsylvania 19104
}

\begin{abstract}
Most axons in the CNS innervate specific subregions or layers of their target regions and form contacts with specific types of target neurons, but the molecular basis of this process is not well understood. To determine whether collapsin-1/semaphorin-III/D, a molecule known to repel specific axons, might guide afferent axons within their cerebellar targets, we characterized its expression by in situ hybridization and observed its effects on mossy and climbing fiber extension and growth cone size in vitro. In newborn mice sema-D is expressed by cerebellar Purkinje cells in parasagittal bands located medially and in some cells of the cerebellar nuclei. Later, sema-D expression in Purkinje cells broadens such that banded expression is no longer prominent, and expression is detected in progressively more lateral regions. By postnatal day 16, expression is observed throughout the cerebellar mediolateral axis.
\end{abstract}

Collapsin-1 protein, the chick ortholog of sema-D, did not inhibit the extension of neurites from explants of inferior olivary nuclei, the source of climbing fibers that innervate Purkinje cells. In contrast, when it was applied to axons extending from basilar pontine explants, a source of mossy fiber afferents of granule cells, collapsin-1 caused most pontine growth cones to collapse, as evidenced by a reduction in growth cone size of up to $59 \%$. Moreover, $63 \%$ of pontine growth cones arrested their extension or retracted. Its effects on mossy fiber extension and its distribution suggest that sema-D prevents mossy fibers from innervating inappropriate cerebellar target regions and cell types.

Key words: cerebellum; mossy fiber; climbing fiber; Purkinje cell; collapsin; semaphorin; basilar pontine nuclei
The ability of growing axons to form stable synaptic contacts with specific target cells reliably during the development of numerous brain regions has been well documented, and several classes of molecules that guide axons to their targets have been identified, including the netrins, ephrins, and collapsin/semaphorins. Many of the molecules involved in the final targeting of axons, however, remain to be identified (for review, see Tessier-Lavigne and Goodman, 1996). The cerebellum already has proved useful in analyzing the specificity of axonal projections (Baird et al., 1992a; Chédotal et al., 1996). The simplicity of connections between afferent axons and their target cells in cerebellar cortex is advantageous in this analysis. The cerebellum is innervated by two major systems of axons, climbing and mossy fibers, each with a

Received May 20, 1998; revised March 4, 1999; accepted March 11, 1999.

This work was supported by National Institute of Neurological Diseases and Stroke Grant NS33214 and a Whitehall Foundation grant (D.B.) and by National Institute of Child Health and Human Development Training Grant HD07467 (S.R.). We are very grateful to Carol Mason, Gregory Mihailoff, Hiroaki Kobayashi, and Stan Ward for commenting on this manuscript and to Carol Mason for allowing a discussion of unpublished work. We thank Florence Frederic for advice and assistance with some of the statistical analysis. BDNF was generously provided by Cephalon, Incorporated.

S.A.R. and J.M.S. contributed equally to this study.

Correspondence should be addressed to Dr. Douglas H. Baird, Department of Neurobiology and Anatomy, MCP Hahnemann School of Medicine, MCP Hahnemann University, 3200 Henry Avenue, Philadelphia, PA 19129.

Dr. Rabacchi's present address: Department of Pathology, College of Physicians and Surgeons, Columbia University, New York, NY 10032.

Dr. Luo's present address: EXELIXIS Pharmaceuticals, South San Francisco, CA 94080.

Copyright (C) 1999 Society for Neuroscience 0270-6474/99/194437-12\$05.00/0 distinct type of target neuron. Climbing fibers originate exclusively from the inferior olivary nuclei in the caudal brainstem, and in the cerebellar cortex they primarily innervate Purkinje cells. Mossy fibers originate from several disparate locations, including specific spinal nuclei, the vestibular nuclei, and the pontine nuclei, but all mossy fibers innervate the same cells in the cerebellar cortex, granule cells and Golgi cells (Palay and Chan-Palay, 1974).

Although mossy fibers, including pontocerebellar fibers, project to specific regions of the cerebellum in a topographically ordered manner (Burne et al., 1978; Eisenman, 1980, 1981; Eisenman and Noback, 1980; Azizi et al., 1981; Mihailoff et al., 1981; Nikundiwe et al., 1994), the cues that guide them to their appropriate termination zones and target cell types are not well understood (Mason et al., 1997). We investigated the role of collapsin-1/ semaphorin-III/D in cerebellar axon guidance because it is expressed in developing cerebellum (Giger et al., 1996; Baird et al., 1997; Zhou et al., 1997). Moreover, sema-D is thought to contribute to the restriction of axonal projections to appropriate regions during the development of the spinal cord and peripheral nervous system (Messersmith et al., 1995; Püschel et al., 1995; Wright et al., 1995; Shepherd et al., 1996, 1997; Behar et al., 1996; Varela-Echavarria et al., 1997; Taniguchi et al., 1997).

Collapsin-1, the semaphorin-III/D ortholog from chicken, was the first protein isolated on the basis of its ability to collapse growth cone structure (Luo et al., 1993). Collapsin-1 is a member of a family of homologous proteins (for review, see Kolodkin, 1996): in chick, the collapsins (Luo et al., 1995); in mouse and 
human, the semaphorins (Kolodkin et al., 1993; Inagaki et al., 1995; Püschel et al., 1995; Adams et al., 1996; Zhou et al., 1997). All of these proteins share homology within a region of $\sim 500$ amino acids, the semaphorin domain. Receptors for semaphorins recently have been identified and characterized (Chen et al., 1997; He and Tessier-Lavigne, 1997; Kolodkin and Ginty, 1997; Kolodkin et al., 1997; Nakamura et al., 1998; Takahashi et al., 1998). Insect species homologs include semaphorin-I (formerly fasciclin IV) and semaphorin-II and also contribute to axon guidance (Kolodkin et al., 1992; Matthes et al., 1995; Wong et al., 1997; Yu et al., 1998).

Here, we report the developmental regulation of sema-D (the mouse ortholog of chicken collapsin-1) expression in Purkinje cells and expression in cerebellar nuclei during the first 3 weeks after birth, a period encompassing much of pontocerebellar mossy fiber development. We also characterize specific growthinhibiting effects of collapsin-1 on extending basilar pontine axons in vitro, axons that develop as mossy fibers in vivo. These results indicate that the guidance of pontocerebellar mossy fibers to appropriate regions of the cerebellum and to their appropriate target neurons, granule cells, may be mediated in part by sema-D expressed by nontarget Purkinje cells.

\section{MATERIALS AND METHODS}

In situ hybridization. A full-length sema-D coding sequence was constructed from fragments amplified by reverse transcription PCR. The identity of the sema-D cDNA was confirmed by sequencing. To obtain riboprobes for in situ hybridization, we cloned the sema-D cDNA into pBluescript SK. The pBluescript/sema-D construct was linearized first with SmaI and HincII to generate sense and antisense probes, respectively. Riboprobes were synthesized with the DIG RNA labeling kit (Boehringer Mannheim, IN). The digoxigenin-labeled RNA probes were precipitated and partially hydrolyzed to reduce the probe length to $\sim 200$ nucleotides.

At least three brains were processed for in situ hybridization and examined at each stage. At a given stage, little variation in the patterns of hybridization was observed between brains. Brains from newborn and 6-d-old mice (C57Bl/6) were dissected, immersion-fixed for $24 \mathrm{hr}$ in $4 \%$ paraformaldehyde in PBS, and cryoprotected in $20 \%$ sucrose. The postnatal (P) day P10-P11, P14-P16, and P19-P21 mice were anesthetized with a cocktail of ketamine $(50 \mathrm{mg} / \mathrm{kg})$, xylazine $(5 \mathrm{mg} / \mathrm{kg})$, and acetopronazine $(0.4 \mathrm{mg} / \mathrm{kg})$ and cardially perfused with $4 \%$ paraformaldehyde in PBS. Then the brains were dissected, cryoprotected in $15 \%$ sucrose, and stored at $-80^{\circ} \mathrm{C}$ before being sectioned. Frozen sections 16-20 $\mu \mathrm{m}$ thick were collected on Superfrost Plus slides (Fisher Scientific, Pittsburgh, PA) and stored at $-20^{\circ} \mathrm{C}$. On the day of hybridization the slides were thawed, washed twice in PBS containing $0.1 \%$ diethyl pyrocarbonate for $15 \mathrm{~min}$, and washed for $15 \mathrm{~min}$ in $5 \times$ SSC. Hybridization was performed as described (Baird et al., 1994; Braissant and Wahli, 1998). Briefly, sections were hybridized for $20 \mathrm{hr}$ at $58^{\circ} \mathrm{C}$ in a humid chamber with DIG-labeled sense or antisense riboprobes $(\sim 0.4$ $\mu \mathrm{g} / \mathrm{ml})$ in hybridization buffer containing $50 \%$ formamide and $10 \%$ dextran sulfate. Sections were washed for $30 \mathrm{~min}$ in $2 \times \mathrm{SSC}$ at $20^{\circ} \mathrm{C}$ (room temperature), for $1 \mathrm{hr}$ in $2 \times \mathrm{SSC}$ at $65^{\circ} \mathrm{C}$, and for $1 \mathrm{hr}$ in $0.1 \times \mathrm{SSC}$ at $65^{\circ} \mathrm{C}$. After $5 \mathrm{~min}$ of equilibration in TBS $(0.1 \mathrm{M}$ Tris, $\mathrm{pH} 7.5$, and 0.15 $\mathrm{M} \mathrm{NaCl}$ ) the sections were incubated for 2-3 hr at room temperature with alkaline phosphatase-conjugated anti-digoxigenin antibody (1:5000; Boehringer Mannheim). Corresponding sections were immunolabeled for the Purkinje cell marker calbindin-D28k by using a rabbit polyclonal anti-calbindin antibody (1:2000; Swant, Bellinzona, Switzerland) in TBS. Calbindin was visualized by indirect immunofluorescence, whereas hybridization was detected by direct alkaline phosphatase immunohistochemistry as described (Baird et al., 1994; Goldman-Wohl et al., 1994). Sections were examined with the microscopic imaging system, as described in Time-Lapse Microscopy and Digital Imaging (below) via bright-field, Nomarski, and fluorescence optics. Sections were photographed with Ektachrome 64T reversal film (Kodak, Rochester, NY). Color slides were scanned at 1200 pixels per inch, and the resulting RGB images were montaged, combined into composite figures, and brightnessand contrast-adjusted via Photoshop 3.0. Except for Figure $1 C-H$, the images were corrected for the uneven illumination inherent in Nomarski optics by dividing raw image pixel values by values in an image of an empty field, and then the images were printed on a Scitex Iris 3047 Digital Color Printer.

Purified, recombinant collapsin-1. A myc-epitope-tagged collapsin-1 fusion protein was produced in insect cells and enriched on a S-Sepharose cation exchange column as described (Shepherd et al., 1997). Conditioned medium from control insect cultures lacking collapsin was processed in the same way and was used as control material. The biological activity of the myc-tagged collapsin-1 preparation was assayed with a previously described dorsal root ganglia (DRG) growth cone collapse assay (Luo et al., 1993). In the present study, collapsin-1 concentrations that collapsed DRG growth cones were applied to growth cones extending from basilar pontine and inferior olivary explants, sources of cerebellar mossy and climbing fibers, respectively.

DRG explant culture. DRGs were obtained from embryonic day (E) 8 chick embryos and from P0 mice. After decapitation, the DRGs were dissected in PBS, partially freed from their connective tissue capsules, and plated in 16-well glass Labtek chamber slides (Nalge Nunc, Naperville, IL) coated first with $0.5 \mathrm{mg} / \mathrm{ml}$ poly-D-lysine [molecular weight (MW) >300,000; Sigma], followed by $20 \mu \mathrm{g} / \mathrm{ml}$ laminin (Life Technologies) in serum-free (SF) medium consisting of Eagle's basal medium with Earle's salts supplemented with $1 \%$ bovine serum albumin (fraction V; Sigma), insulin (10 $\mu \mathrm{g} / \mathrm{ml}$; Sigma), transferrin $(100 \mu \mathrm{g} / \mathrm{ml}$; Sigma $)$, sodium selenite (30 nM; Sigma), putrescine (100 $\mu \mathrm{M}$; Sigma), progesterone (20 nM; Sigma), glucose (final, $32 \mathrm{~mm}$ ), $20 \mathrm{U} / \mathrm{ml}$ each of penicillin and streptomycin (Life Technologies), and $2 \mathrm{~mm}$ L-glutamine (Life Technologies), pH 7.4. NGF (25 ng/ml; Upstate Biotechnologies, Lake Placid, NY) was added shortly after plating. After $\sim 24 \mathrm{hr}$ the cultures were fixed in $4 \%$ paraformaldehyde in PBS and immunolabeled, using an anti-actin antibody (1:100; Chemicon, Temecula, CA) and the indirect peroxidase method. Other slides were fixed, but not labeled, and analyzed by phase-contrast optics. Growth cones were observed with a Zeiss Axiovert inverted microscope (Oberkochen, Germany) equipped with a $63 \times$ "dry" objective and were scored as collapsed or spread by using previously described criteria (Raper and Kapfhammer, 1990; Shepherd et al., 1997).

Assay of collapsin-1 activity on growth cones from mouse neurons. To determine whether collapsin-1 (the chicken protein) is active on mouse neurons, we compared the ability of collapsin-1 to collapse growth cones extending from explanted DRG taken from newborn mice and E8 chick and cultured in NGF-containing medium. A similar percentage of growth cones from either species was observed to collapse after exposure to 50 $\mathrm{ng} / \mathrm{ml}$ collapsin-1 for $40 \mathrm{~min}$ ( $56 \%$ for mouse vs $61 \%$ for chick). In both species the percentage of collapsed growth cones was significantly less $(p<0.01)$ when treated with medium lacking collapsin-1 (16\% for mouse; $27 \%$ for chick).

Identification of the basilar pontine nuclei. The position of the basilar pontine nuclei (BPN; also called the pontine gray or basal pontine gray) is relatively easy to establish because of the superficial location of the nuclei and because they protrude rostrally from the pons toward the base of the gap formed by the mesencephalic flexure. To confirm the location of the BPN in newborn mice for purposes of dissection and culture, we labeled axonal projections from the BPN by using DiI. We labeled BPN projections anterogradely, because many axons of the BPN have not yet reached the cerebellum at birth, the time when we wished to culture the BPN, making retrograde labeling difficult. Published methods were used to trace axonal projections with DiI (Baker and Reese, 1993). Briefly, three newborn mice were sacrificed, and their brains were dissected and fixed as described for in situ hybridization but were left in $4 \%$ paraformaldehyde in PBS. After the pial membranes were removed, DiI (Molecular Probes, Eugene, OR) crystals were placed immediately below the pontine surface within the region dissected as the BPN in this and previous studies (Baird et al., 1992a,b, 1996). Brains were incubated at $37^{\circ} \mathrm{C}$ to increase the rate of diffusion of DiI in axonal membranes. After $9 \mathrm{~d}$ the brains were fixed, imbedded in gelatin, and sectioned at $100 \mu \mathrm{m}$ on a vibratome. Sections were mounted in Fluroguard (Bio-Rad, Hercules, CA) and viewed with a fluorescence microscope with 5, 10, and $20 \times$ objective lenses. When frontally sectioned brains were examined between 9 and $14 \mathrm{~d}$ after DiI application, a prominent bilateral tract of axons was labeled with DiI. The labeled tract projected in a dorsal and posterior direction up and around the brainstem, initially superficially, but deeper in more posterior sections. The labeled axons were identified as running within the medial cerebellar peduncle, the pathway to the cerebellum, followed by basilar pontine axons. Thus, we could be confi- 
dent that the brain region dissected in the subsequent analysis corresponded to the BPN, a region proven to be a highly homogeneous source of cerebellar mossy fibers (Brodal et al., 1988; Nikundiwe et al., 1994).

Identification of inferior olivary nuclei. Inferior olivary nuclei were dissected from the medullae of embryos on day 17 of gestation. At this stage the axons from inferior olivary nuclei are beginning to innervate the cerebellum and will extend in culture. To confirm the identity of explants, we labeled both explants and sections of the inferior olivary nuclei by using antibodies to calbindin-D28k and indirect immunofluorescence. In sections, groups of calbindin-positive cells were found in portions of the inferior olivary nuclei, as was reported previously (Wassef et al., 1992). In brainstem regions surrounding the olive, only scattered isolated cells occasionally were observed, and most regions lacked calbindin labeling. Many of the explants also were found to contain groups of calbindin-positive cells that extended calbindin-positive axons from the explants. The presence of clusters of calbindin-positive cells in portions of both sectioned and explanted inferior olivary nuclei confirmed the identity of the explants as derived from the inferior olive.

Explant culture of mossy and climbing fiber sources. Explant sources of mossy and climbing fibers were dissected from the BPN and inferior olivary nuclei, respectively. Previously described methods were used for the BPN cultures (Baird et al., 1992a,b, 1996) and adapted for explants of inferior olivary nuclei. Briefly, the BPN were recognized as ventroanterior swellings on the base of the pons and dissected. Micro-explants of $\sim 200 \mu \mathrm{m}$ in diameter were cut from the dissected BPN and cultured in microwell chambers consisting of coverslips affixed beneath a $5.5 \mathrm{~mm}$ hole punched in a $50 \mathrm{~mm}$ bacteriological plate (Baird et al., 1994). Inferior olivary nuclei were dissected from the portion of the medial brainstem just rostral to the flexure in the caudal portion of the medulla (cervical flexure) and extending $\sim 25 \%$ of the distance from this flexure to the BPN.

To confirm that in the present culture conditions nearly all of the neurites extending from pontine explants would develop as mossy fibers in vivo, we labeled explant neurites with anti-GABA antibodies and found that most GABA-positive neurites were found within the explant, whereas a large majority ( $>95 \%$ ) of neurites extending from the explant were unlabeled, indicating that they originate from pontocerebellar projection (mossy fiber) neurons.

Coverslips were coated and washed, first with poly-D-lysine (MW $>300,000$; Sigma), followed by laminin $(20 \mu \mathrm{g} / \mathrm{ml}$; Life Technologies). Explants were cultured at $37^{\circ} \mathrm{C}$ in a $5 \% \mathrm{CO}_{2}$ incubator in $100 \mu \mathrm{l}$ of the SF medium described for DRG culture. To promote appreciable neurite outgrowth from inferior olivary nuclei, we first had to condition the SF medium with cerebellar astrocytes and supplement it with $10 \mathrm{ng} / \mathrm{ml}$ BDNF (a gift from Cephalon, West Chester, PA). Similar effects of collapsin- 1 on pontine neurites were observed in SF medium or conditioned SF medium with BDNF. To allow for comparisons between pontine and olivary growth cones, we conducted most of the experiments that are described by using conditioned SF medium with BDNF. Cerebellar astrocytes were isolated for conditioning medium by dissociating P4-P5 rat cerebella in $1 \%$ trypsin and plating $1 \times 10^{7}$ cells on uncoated $75 \mathrm{~cm}^{2}$ tissue culture plastic flasks or $150 \mathrm{~mm}$ tissue culture plates (Corning-Costar, Cambridge, MA). After $1 \mathrm{~d}$ of culture in $10 \%$ horse serum medium [Eagle's basal medium with Earle's salts (Sigma) supplemented with horse serum (Life Technologies), glucose, penicillin/streptomycin, and L-glutamine], non-neuronal cells, predominantly astrocytes, adhered to the culture surface although most neurons did not. Neurons were washed from the cultures with PBS, and fresh $10 \%$ horse serum medium was added. Astroglia were cultured for $\sim 2$ weeks at $37^{\circ} \mathrm{C}$ in $5 \%$ $\mathrm{CO}_{2}$, at which time the horse serum medium was replaced with $\mathrm{SF}$ medium. After $3 \mathrm{~d}$ the now conditioned SF medium was removed and supplemented with BDNF $(10 \mathrm{ng} / \mathrm{ml})$, and the $\mathrm{pH}$ was adjusted to 7.4.

Analysis of growth cone area. BPN explants were cultured as described above except that they were plated in 16-well Labtek chamber slides first coated with poly-D-lysine and laminin as described for microwells. Explants were cultured for $24 \mathrm{hr}$ at $37^{\circ} \mathrm{C}$ in $5 \% \mathrm{CO}_{2}$, and then purified recombinant collapsin-1 or control material was applied and the cultures were returned to the incubator for $40 \mathrm{~min}$. Next the cultures were fixed in $4 \%$ paraformaldehyde in PBS and labeled with anti-actin antibodies and the indirect peroxidase method. The tips of neurites were imaged digitally, as described below, but with a $40 \times$ Plan-Neofluar objective lens. Growth cone areas were measured with ONCOR Image analysis software. Pixel values in raw images were divided by the corresponding value in the image of an empty field to correct for any unevenness in illumination and any differences in the response of different pixels on the camera CCD. Regions of interest (ROIs), each containing a single neurite tip, were selected from larger images. ROIs were drawn such that each neurite tip delimited by one of the boundaries of the ROI contained a fixed length of neurite as measured from the distal tip of neurites or growth cones. For each ROI a window of gray values was chosen such that the values of pixels within the neurite, and its growth cone if present, were included within the window, but pixel values representing the culture surface surrounding the neurite tip were excluded. The number of pixels in the area defined by the window of pixel values was determined and converted to an area in square micrometers $\left(\mu \mathrm{m}^{2}\right)$.

Area measurements of unlabeled growth cones, including those observed during time-lapse experiments, were obtained from phasecontrast images. National Institutes of Health Image 1.60 software was used to trace growth cone lamellae, and the area of the resulting closed curve was recorded. In a few instances area measurements could not be made on growth cones observed during time-lapse microscopy, such as if a growth cone was not in sharp focus during the desired time interval. In addition, a few growth cones that were included in the area analysis were excluded from the analysis of rates of neurites extension if, for example, a growth cone contacted another neurite shortly after the 30 min that followed collapsin or control treatment. For these reasons the numbers of growth cones in the area and time-lapse analyses are not identical.

Time-lapse microscopy and digital imaging. Microwell coverslip dishes containing micro-explants of either BPN (mossy fiber source) or inferior olivary nuclei (climbing fiber source) were prepared (see above) and cultured for $18 \mathrm{hr}$ in conditioned SF medium supplemented with $10 \mathrm{ng} / \mathrm{ml}$ BDNF. Cultures for time-lapse microscopy were transferred to a medium suitable for use in atmospheric $\mathrm{CO}_{2}$ by gently flooding the microwell and surrounding plate with $2.5 \mathrm{ml}$ of $15 \mathrm{~mm}$ HEPES-buffered conditioned medium containing $10 \mathrm{ng} / \mathrm{ml}$ BDNF. The tight-fitting lid was replaced with one containing a hole covered with Parafilm, such that the Parafilm could be lifted, solutions added, and the Parafilm replaced. Cultures then were placed on the heated stage of a Zeiss Axiovert 135-TV inverted microscope at $35^{\circ} \mathrm{C}$, and digital images were acquired with a $40 \times$ Acroplan phase objective, a Photometrics NU-200 high-resolution cooled CCD camera, and ONCOR image acquisition and processing software running on an Apple Macintosh Quadra 950 computer. Microscopic fields were located that contained three to five growth cones, and images of one such field were collected every $60 \mathrm{sec}$ for periods ranging from 90 to $300 \mathrm{~min}$. The resulting 12 bits per pixel images were scaled linearly to eight bits per pixel, and images were combined into composite figures with Photoshop 3.0 software (Adobe Systems, Mountain View, CA). Images were printed on an image setter at 2400 dots per inch.

Analysis of neurite extension. Images of neurites from a time-lapse series were analyzed with National Institutes of Health Image 1.60 software. Fixed points were used to determine a reference point on each neurite, which served as an origin from which to measure the length of single neurites over an entire experiment. Images representing time intervals of $5 \mathrm{~min}$ were analyzed. Neurites always were measured from the same reference point along the usually curving neurite to the tip of the leading lamellipodium of the growth cone. Filopodia were not measured. Growth cones were observed for at least $30 \mathrm{~min}$ before the addition of collapsin-1 or control material, and only growth cones advancing steadily during this period were analyzed further to ensure that only neurites from viable cells were analyzed. Then the neurite lengths from each experiment were plotted versus time at $5 \mathrm{~min}$ intervals. Data from different experiments were pooled by calculating the average velocity for growth cones during $30 \mathrm{~min}$ intervals before and after the addition of material. The average velocity during the $30 \mathrm{~min}$ intervals was converted to a percentage of the velocity before treatment and was plotted. The Student's $t$ test was used to compare the distributions of growth cone velocities between groups with or without collapsin-1 within the same time interval.

\section{RESULTS}

Distribution of semaphorin-D in developing cerebellum

We used in situ hybridization to analyze the regional and cellular distribution as well as the temporal regulation of sema-D. Riboprobes for hybridization were prepared from a full-length sema-D cDNA. Specificity of hybridization was determined by using a sense sema-D riboprobe.

In frontal sections from newborn mice, sema-D expression was most prominent medially in the developing vermis, in bands on 

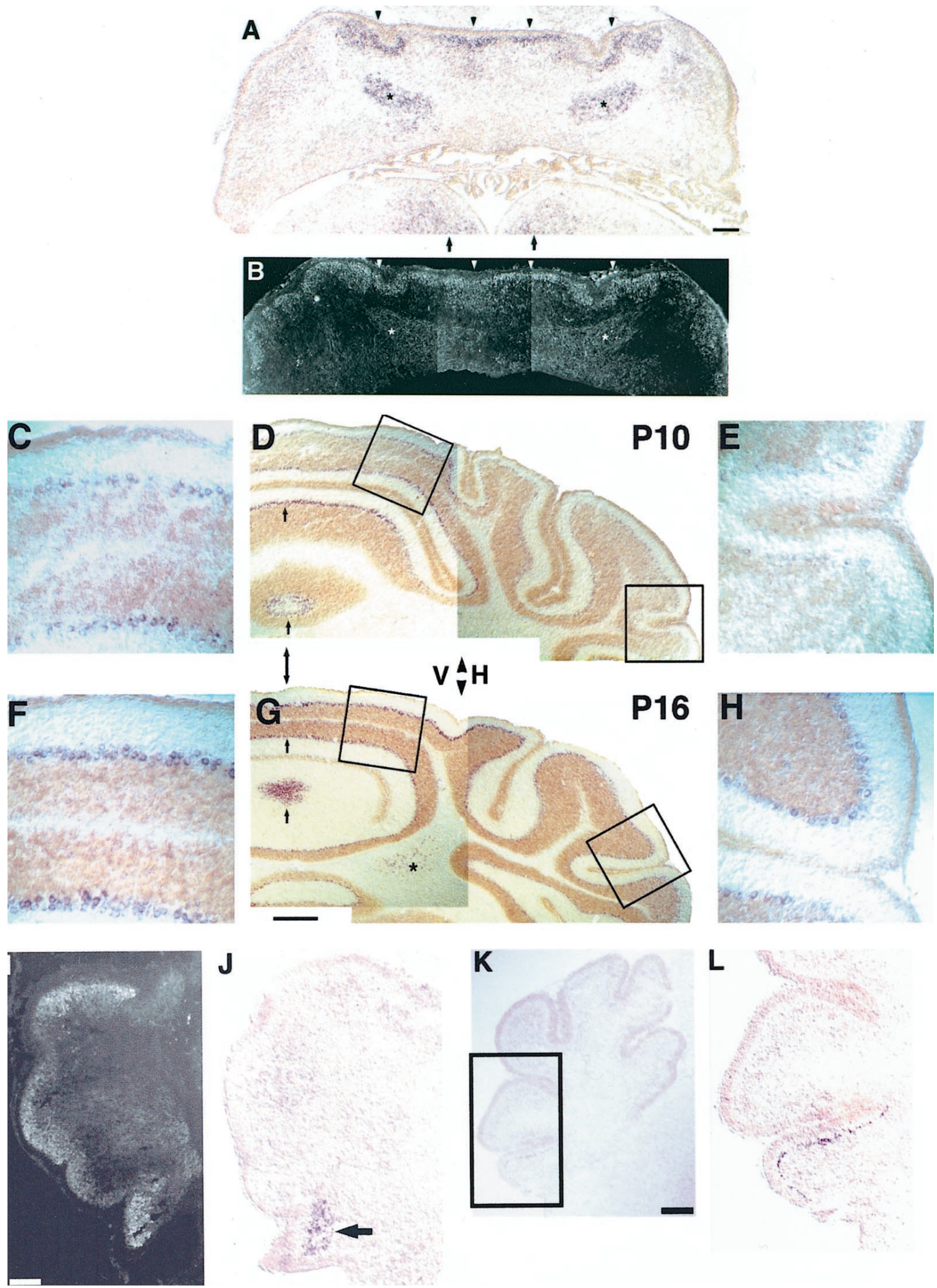

Figure 1. In situ hybridization of sema-D in postnatal cerebellum. $A$, Sema-D expression at $\mathrm{P} 0$ is prominent in four bands of cells flanking the midline in the developing Purkinje cell layer (arrowheads). Expression is absent at the midline itself and also is absent or very low lateral to the expressing cells in the developing cerebellar hemispheres. Expression also is present in cells of the developing cerebellar nuclei (asterisks) and in or near the developing hypoglossal nuclei of the brainstem beneath the cerebellum (arrows). $B$, Cerebellar section adjacent to $A$, immunolabeled for the Purkinje cell marker calbindin-D28k. Calbindin-positive cells are found in areas of sema-D expression (arrowheads, compare with $A$ ) and in areas with little or no expression (between arrowheads), including the midline and much of the developing hemispheres (lateral to arrowheads). Asterisk in $B$ indicates labeling of calbindin-positive Purkinje cell axons. $C-H$, Sema-D expression at P10 $(C-E)$ and $\mathrm{P} 16(F-H)$. $C, F$, Purkinje cells of developing vermis show high expression at $\mathrm{P} 10(C)$ and $\mathrm{P} 16(F) . D, G$, Low magnification of $\mathrm{P} 10(D)$ and $\mathrm{P} 16(G)$. Hybrids are indicated by the purple product (Figure legend continues) 
either side of the midline (Fig. 1A). These expressing bands coincided with the location of Purkinje cells in adjacent sections, as demonstrated by immunolabeling with a Purkinje cell marker, calbindin-D28k (Fig. 1B). Between these expressing bands, sema-D was not detected in a small region $\sim 70 \mu \mathrm{m}$ wide centered on the midline. Little or no expression was detected in Purkinje cells in large areas lateral to the expressing bands, areas that included most of the developing hemispheres. The medially located bands of expressing Purkinje cells were several cells thick in the dorsoventral (radial) axis; at birth, Purkinje cells have yet to complete their migration and form a layer one cell thick. The medial pair of bands of expressing cells was observed throughout the rostrocaudal cerebellar axis. Within bands as many as $25 \%$ of Purkinje cells, identified by calbindin double-labeling, were found to have little or no sema-D expression in some sections.

Except for approximately the most anterior quarter of the cerebellar rostrocaudal axis, where a single pair of expressing bands was most prominent, a second more laterally located pair of bands was evident throughout most of the cerebellum (Fig. 1A). Bands of Purkinje cells with little or no expression separated the two bilaterally symmetric pairs of expressing bands. All four expressing bands were confined to a region spanning $\sim 60 \%$ of the cerebellar mediolateral axis.

Some calbindin-negative cells of newborns also were found to express sema-D (Fig. 1, asterisks). These cells are most likely developing cerebellar nuclear neurons because of their location (often in the developing white matter), their lack of calbindin, their neuronal morphology, and their association with calbindinpositive axons from Purkinje cells (see calbindin-labeled fibers around asterisks of Fig. $1 B$ ).

By day 10 Purkinje cells expressing sema-D could be detected in lateral, as well as medial, regions of the cerebellar cortex in frontal sections, but expression in medial regions, including the developing vermis, remained substantially higher (Fig. $1 C-E$ ). Expression within the developing vermis, however, remained nonuniform. Bands of Purkinje cells with high expression were interspersed with generally smaller bands of Purkinje cells with little or no expression. A mediolateral gradient of expression was superimposed on the banded expression at P10. Expression was highest in Purkinje cells near the midline (Fig. 1C,D) and gradually decreased to near the limits of detection in the most lateral regions (Fig. 1D,E). Sema-D expression persisted in some cells of the cerebellar nuclei at P10 (data not shown).

At P16, Purkinje cells of the lateral hemispheres showed higher levels of sema-D expression than at P10 (compare Fig. $1 D, E$ with $G, H)$, although expression in lateral Purkinje cells was still lower than in more medial regions. Expression persisted within the cerebellar nuclei (Fig. 1G). At P19-P21, expression was similar to P16 in that all or nearly all Purkinje cells had moderate levels of sema-D expression, but the difference between medial and lateral levels of expression was less apparent (data not shown).

There was one exception to the general observation that sema-D expression was low in lateral cerebellum at P10 and earlier stages. At birth, portions of the developing inferior lobe (flocculonodular lobe) exhibited appreciable expression of sema-D, which persisted during the subsequent postnatal stages that were examined (Fig. 1I,J). Sema-D in the presumptive floccular lobule (flocculus) was notable because laterally located Purkinje cells in other lobules did not express sema-D until after day 10. At P6 the flocculus was the only lobule located in the lateral hemispheres that expressed sema-D (Fig. $1 K, L$ ). Expression persisted in the flocculus at P10 (data not shown).

In summary, sema-D-expressing cerebellar cells included both Purkinje cells and some nuclear cells. At early postnatal stages, Purkinje cell expression was confined to parasagittal bands located medially, except for lateral expression in the floccular lobule of the inferior lobe. At later postnatal stages, Purkinje cell expression progressively broadened such that by day 10 most medial Purkinje cells expressed sema-D, and by day 16 few laterally located Purkinje cells were found to lack expression.

\section{Time-lapse microscopy of axons from basilar pontine and inferior olivary nuclei during collapsin-1 application}

Studies of spinal cord development and of mice with a disrupted sema-D gene indicate that collapsin-1/semaphorin-III/D serves to prevent responsive growth cones from entering inappropriate target regions (Taniguchi et al., 1997) (for review, see Kolodkin, 1996). For this reason we chose to determine whether collapsin-1 acts on growth cones of cerebellar afferents that form and do not form synaptic connections with Purkinje cells, those of climbing and mossy fibers, respectively. The inferior olivary nuclei are the source of all cerebellar climbing fibers. We selected the BPN as a source of mossy fibers because, in mammals, the BPN are the major source of cerebellar mossy fibers (Brodal and Bjaalie, 1992; Altman and Bayer, 1996), they are readily accessible for dissection, and they are relatively homogeneous (only $1-5 \%$ of BPN neurons or fewer are GABAergic interneurons in all species examined; Brodal et al., 1988).

Time-lapse microscopy was used to analyze the response of growth cones to collapsin-1. BPN explants from newborn mice or inferior olivary explants from E17 embryos were plated in coverslip microwell plates (Baird et al., 1994), and 18-24 hr later neurite extension was observed with time-lapse microscopic dig-

\section{$\longleftarrow$}

of alkaline phosphatase histochemistry. Brown areas are the external germinal layer (EGL) seen, for example, at the edges of the sections and the larger developing internal granule layer (IGL), seen adjacent to the purple sema-D-expressing Purkinje cells. The brown coloration was nonspecific and also was present in sense controls (data not shown). A double-headed arrow indicates the approximate location of the midline. The arrowheads between $V$ and $H$ indicate the approximate boundary between vermis $(V)$ and hemisphere $(H)$. Arrows indicate examples of sema-D expression in the Purkinje cell layer. At P10 $(D)$ expression in the Purkinje layer is nonuniform, with areas of low expression interspersed with areas of higher expression. At P16 $(G)$ expression in the vermal Purkinje layer is more homogeneous, but vermal expression is still higher than in the hemisphere. An asterisk indicates expression in cerebellar nuclei, which are only visible in the P16 section $(G)$. Boxed areas at left indicated medial locations shown at higher magnification in $C$ and $F$. Boxed areas at right indicate lateral locations shown at higher magnification in $E$ and $H$. $E, H$, Purkinje cells of developing hemisphere show little expression at $\mathrm{P} 10(E)$ and higher expression at P16 $(F)$. I-L, Early postnatal sema-D expression in the lateral cerebellar hemispheres is confined to the region of the developing flocculus. $I$, At birth the developing Purkinje cell layer is revealed by calbindin immunolabeling of a very anterior frontal section. $J$, A section neighboring $I$. High levels of sema-D hybridization (arrow) are seen in the region containing the most ventral Purkinje cells, located within the developing flocculus. $K$, At P6 a low-magnification image is shown for orientation. $L$, The boxed area in $K$ is shown at higher magnification to reveal hybridization in the Purkinje cell layer of the most ventral lobule of this very anterior frontal section. This region is part of the developing flocculus. Little or no hybridization is present in the neighboring lobules. Scale bars: $A, B, 270 \mu \mathrm{m} ; C, E, F, H, 40 \mu \mathrm{m} ; D, G, 160 \mu \mathrm{m} ; I, 110 \mu \mathrm{m} ; J, 100$ $\mu \mathrm{m} ; K, 200 \mu \mathrm{m} ; L, 100 \mu \mathrm{m}$. 

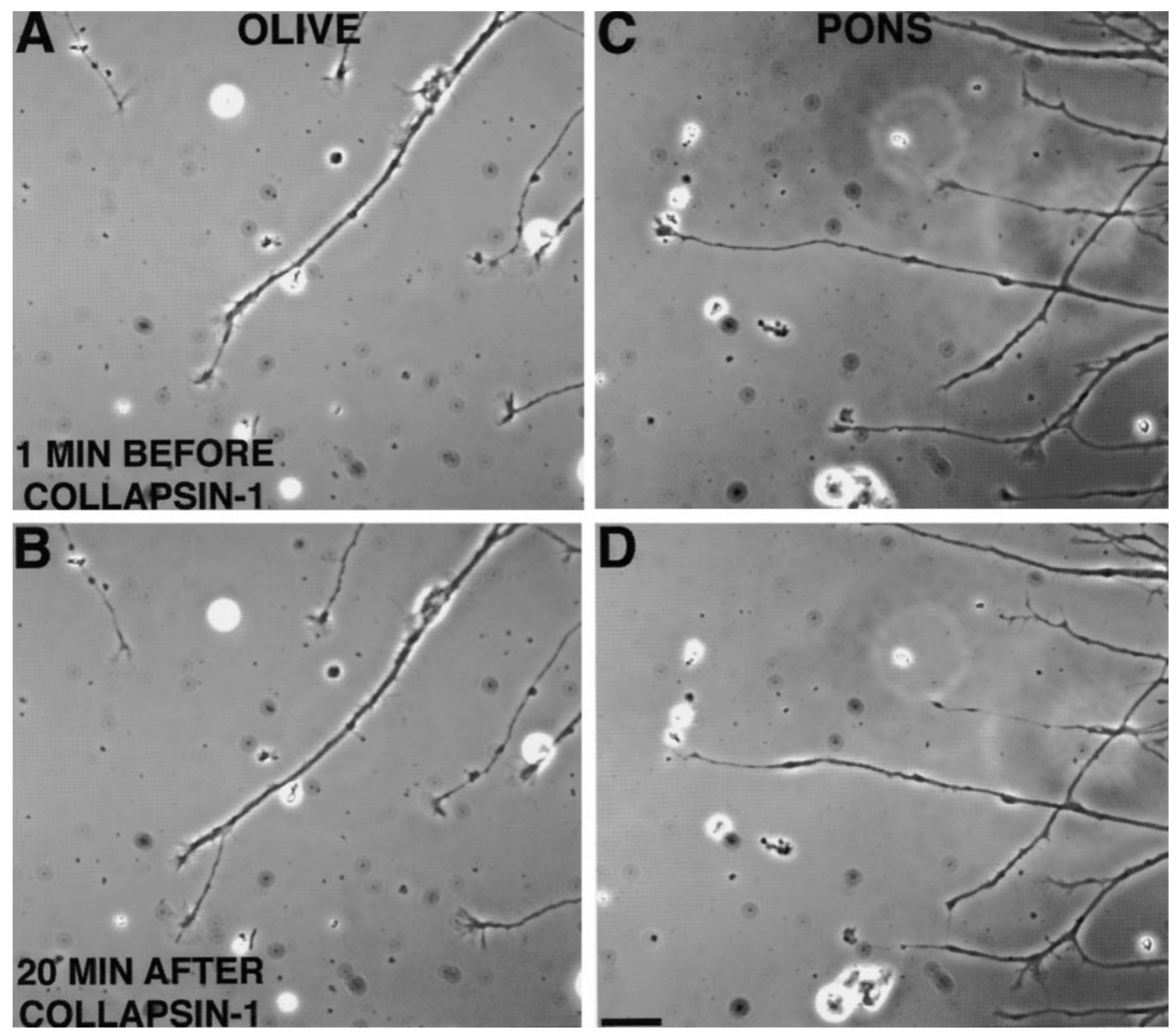

Figure 2. Effect of collapsin-1 on growth cones from inferior olivary nuclei $(A, B, O L I V E)$ and basilar pontine nuclei $(C, D, P O N S)$. Most olivary growth cones maintained their lamellipodia and continued to advance after exposure to collapsin- $1(\sim 50 \mathrm{ng} / \mathrm{ml})$ for $20 \mathrm{~min}$ (compare $A$ and $B)$. Most pontine growth cones collapsed within $20 \mathrm{~min}$ after collapsin-1 exposure $(\sim 20 \mathrm{ng} / \mathrm{ml})$ and became neurites with tapered endings that did not extend further or retracted slightly (compare $C$ and $D$ ). Scale bar, $20 \mu \mathrm{m}$.

ital imaging. For collapsin-1 experiments a total of $27 \mathrm{BPN}$ growth cones was observed in cultures derived from 13 different mice, whereas in control experiments 23 growth cones were observed in cultures derived from eight mice. For collapsin-1 experiments we also observed 24 olivary growth cones in cultures derived from 10 mice, whereas in control experiments 23 growth cones were observed in cultures derived from seven mice.

Within 20 min after the addition of collapsin-1 to the culture medium at $50 \mathrm{ng} / \mathrm{ml}$, most BPN growth cones stopped extending, their lamellipodia collapsed, and in some cases their neurites retracted (Fig. 2C,D). In contrast, growth cones from inferior olivary explants remained spread and continued to advance in collapsin-1 (Fig. 2A,B). These effects of collapsin-1 were quantified in the experiments described below.

As a control, material prepared with a vector lacking the collapsin-1 gene was applied to growing axons in culture. When control material was added to 23 actively extending BPN growth cones, $19(83 \%)$ continued to advance whereas three $(13 \%)$ stopped advancing and one retracted (4\%). By comparison, in collapsin-1-treated cultures $63 \%$ of growth cones stopped advancing or retracted (Fig. $3 A$ ).
To determine whether the action of collapsin- 1 on mossy fibers was specific, we conducted similar experiments by using inferior olivary nuclei explants as a source of climbing fibers. Purkinje cells, which express sema-D, are innervated by climbing fibers but not mossy fibers in the mature cortex. In contrast to the effects of collapsin-1 on pontine neurite extension, collapsin-1 did not prevent the extension of neurites from olivary explants. Of 24 olivary growth cones that were extending before collapsin-1 addition, only four (17\%) stopped extending or retracted within the $30 \mathrm{~min}$ interval after collapsin-1 application, whereas 20 (83\%) continued to advance. Similar results were obtained with control material; of 23 olivary growth cones only five (22\%) stopped or retracted, whereas 18 (78\%) continued to advance (Fig. 3B).

We also analyzed the effect of collapsin on rates of neurite extension to determine whether collapsin might have additional effects short of arrest of extension or retraction. In control material the mean rate of BPN neurite extension declined over the 90 min observation period. During the $30 \mathrm{~min}$ period before the addition of control material the extension rate was $41 \mu \mathrm{m} / \mathrm{hr}$. The extension rate declined to $20 \mu \mathrm{m} / \mathrm{hr}$ (49\% of the pretreatment value) between 60 and $90 \mathrm{~min}$ after the addition of control 
A

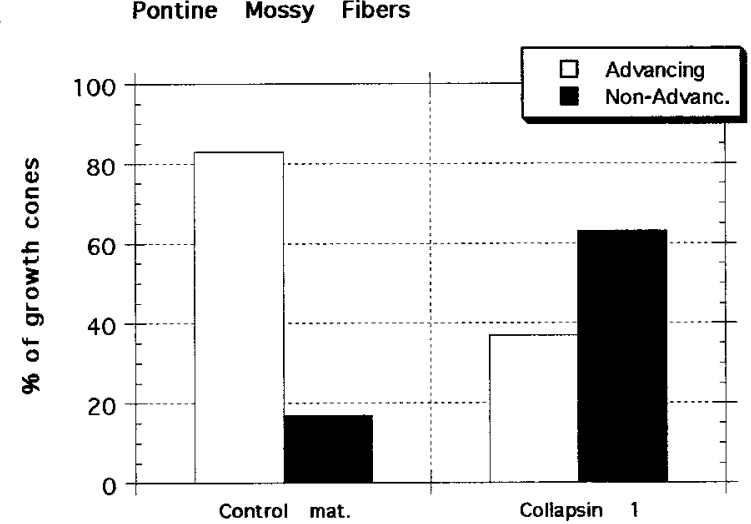

B

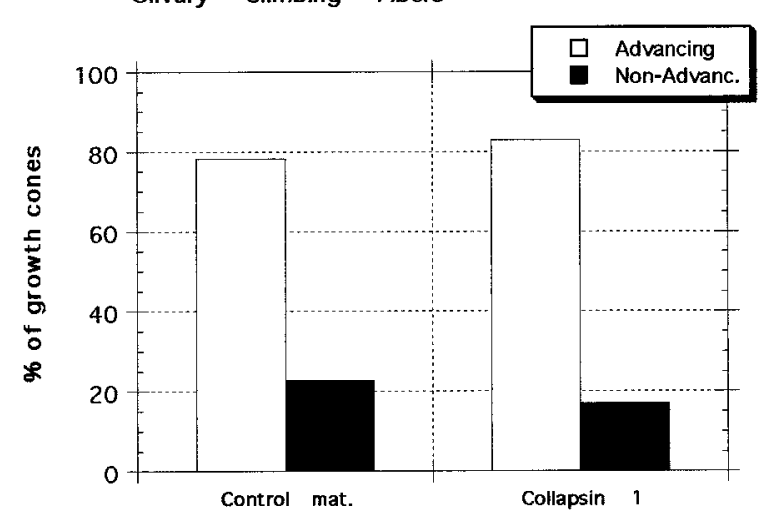

Figure 3. Response of pontine and olivary growth cones to collapsin-1 and control material. Neurites were scored as either advancing or nonadvancing on the basis of their rate of extension between 15 and 30 min after treatment. $A$, Pontine mossy fibers. Most growth cones from basilar pontine neurites continue to advance after the addition of control material, and few growth cones are seen to arrest their extension or to retract. The growth cones that either arrest their extension or retract are referred to as Non-Advanc. When collapsin-1 is applied to pontine growth cones, $63 \%$ collapse and then arrest their extension or retract. $\chi^{2}$ analysis indicates that the frequency of responses of pontine neurites to collapsin- 1 is significantly different $(p<0.003)$ from their response to control material and significantly different from the responses of olivary neurites to either collapsin-1 or control material. $B$, Olivary climbing fibers. The responses of neurites extending in collapsin- 1 or control material were similar; $\sim 80 \%$ of neurites continued to advance.

material (Fig. $4 A$, open bars). Despite the reduction in velocity, pontine growth cones have been observed to advance in vitro for periods of 4.5-15 hr (Baird et al., 1992b; Baynard et al., 1997) and in excess of $2.5 \mathrm{hr}$ in the present study (see below).

During the $30 \mathrm{~min}$ interval before the addition of collapsin, BPN neurites tipped with growth cones were found to extend at a mean rate of $39 \mu \mathrm{m} / \mathrm{hr}$. The mean extension rate decreased to $5.3 \mu \mathrm{m} / \mathrm{hr}$ (13.5\% of pretreatment rate) between 30 and $60 \mathrm{~min}$ after collapsin and continued to decline to $3.4 \mu \mathrm{m} / \mathrm{hr}(8.7 \%$ of pretreatment rate) when measured between 60 and 90 min after collapsin (Fig. 4A, filled bars).

In contrast, the rate of extension of olivary neurites was not reduced significantly by collapsin when compared with growth cones treated with control material (Fig. 4B). After $30 \mathrm{~min}$ in control material the rate of neurite extension declined to $62 \%$ of the pretreatment rate, whereas in collapsin- 1 the decline was only to $89 \%$ of the initial rate. Because of this smaller decline,
A Pontine Mossy Fibers

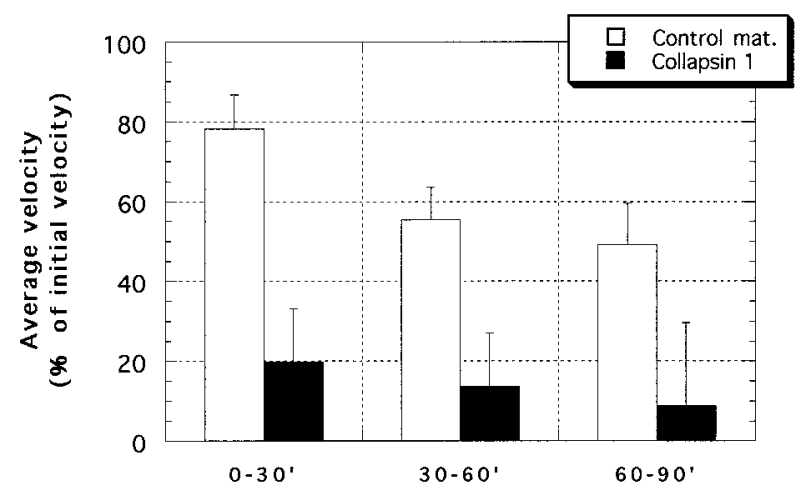

B Olivary Climbing Fibers

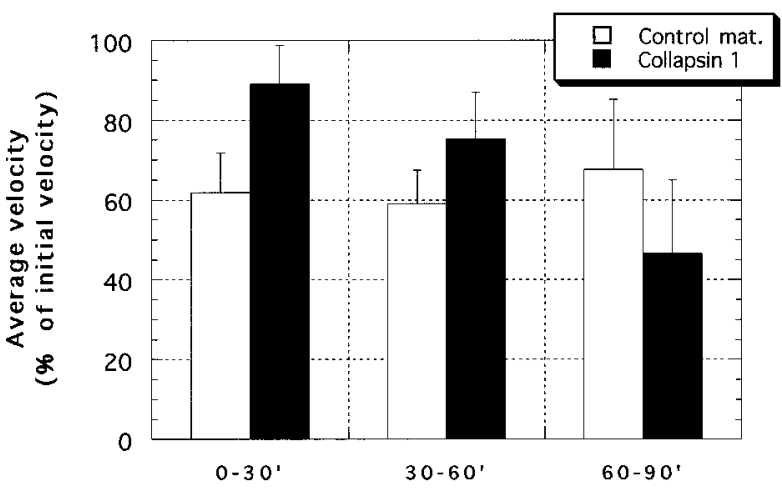

Figure 4. Mean rates of neurite extension from pontine and inferior olivary explants after the addition of collapsin- 1 or control material. $100 \%$ $=$ mean rate of neurite extension during the $30 \mathrm{~min}$ before the addition of collapsin or control material. Collapsin-1 (20 or $50 \mathrm{ng} / \mathrm{ml}$ final) was added to the cultures at time $=0 . A$, Pontine mossy fibers. By 30 min after collapsin-1 ( filled bars) application, growth cone velocities declined to $<20 \%$ of their initial velocity. By 90 min after collapsin- 1 application the mean rate of neurite extension was reduced to $<10 \%$ of the mean initial rate. During the $90 \mathrm{~min}$ after control material (open bars) application, pontine neurites slowly reduced their rate of extension to $\sim 50 \%$ of their initial rate. The reduced extension rate of pontine neurites in collapsin-1 was highly significant $(p<0.001)$ as compared with extension in control material or with olivary neurites with either collapsin-1 or control material. $B$, Olivary climbing fibers. Between 0 and 30 min after treatment, neurite extension rates were significantly higher in collapsin-1 than in control material ( $p<0.015$, unpaired $t$ test). Between 30 and $60 \mathrm{~min}$ and then between 60 and $90 \mathrm{~min}$ after treatment there was no significant difference between extension rates of collapsin- and control-treated neurites. Numbers of growth cones: pontine + collapsin- $1=27$; pontine + control material $=23$; olivary + collapsin $-1=24$; olivary + control material $=23$.

collapsin-1-treated growth cones were significantly faster than corresponding control-treated growth cones $(p<0.05)$. This collapsin-1-induced delay of the deceleration of neurite extension was transient and was observed only during the $30 \mathrm{~min}$ after collapsin-1 application. During the intervals $30-60$ and $60-90$ min after treatment, the rates of neurite extension in olivary cultures treated with control material or collapsin were not significantly different.

The BPN (mossy fiber) growth cones that stopped advancing in collapsin (17 of 27 growth cones) could be subdivided further: 11 growth cones $(41 \%)$ collapsed and then retracted (examples, Fig. 
A

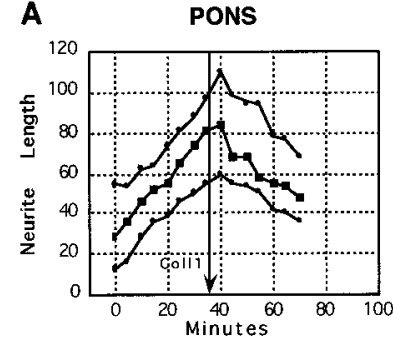

C

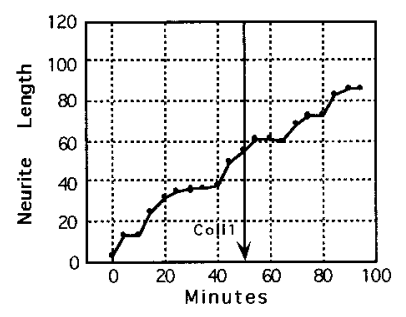

B

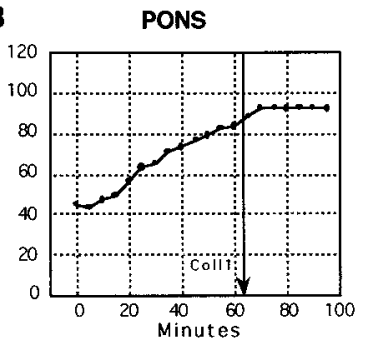

D

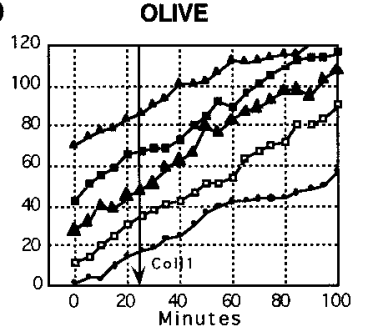

E PONS

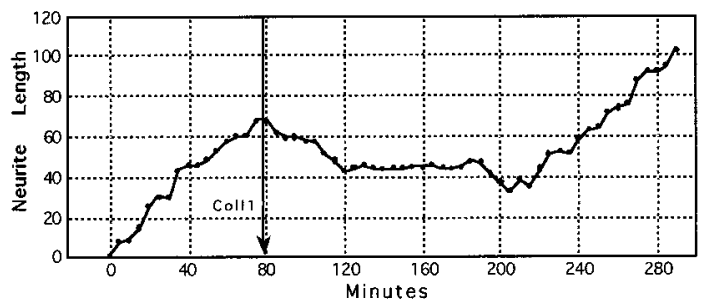

Figure 5. Neurite length versus time for individual pontine $(A-C, E)$ and olivary growth cones $(D)$ after the addition of collapsin-1 $(50 \mathrm{ng} / \mathrm{ml})$. Each trace represents the extension of a single growth cone. Each graph represents growth cones observed in a separate culture. $A$, Pontine neurite extension is initially steady, but neurites rapidly retract after collapsin-1 addition (arrow); $\sim 40 \%$ of pontine growth cones exhibit this response to collapsin-1. $B$, Pontine neurite extends and then rapidly arrests after collapsin-1 addition; $\sim 20 \%$ of pontine growth cones exhibit this type of response to collapsin-1. $C$, Pontine growth cone does not alter its advance after collapsin-1 addition; $\sim 40 \%$ of pontine growth cones continue to advance in collapsin-1. $D$, Examples of the $\sim 80 \%$ of growth cones from inferior olivary explants that do not alter their extension rates after the application of collapsin-1. $E$, Long-term observation of a pontine growth cone. Approximately $2 \mathrm{hr}$ after collapsin-1-induced neurite retraction the growth cone recovered and advanced at a rate comparable to that before collapsin addition (arrow).

$5 A)$ and 6 growth cones $(22 \%)$ collapsed and then stopped extending (examples, Fig. 5B). The remaining 10 growth cones $(37 \%)$ continued to extend in collapsin-1 (example, Fig. 5C) at a mean rate of $30 \mu \mathrm{m} / \mathrm{hr}$, which was not significantly different from that of advancing growth cones treated with control material during a comparable $30 \mathrm{~min}$ interval $(32 \mu \mathrm{m} / \mathrm{hr})$. Nearly all growth cones (15 of 17) that stopped advancing or that retracted after the addition of collapsin did not exhibit any further neurite extension 30-90 min after collapsin treatment. Again, collapsin-1 had no effect on the rate of olivary neurite extension (Fig. 5D).

A few growth cones were observed for extended periods after collapsin treatment. The three of five growth cones that had collapsed previously and retracted later started to extend again $\sim 2 \mathrm{hr}$ after collapsin-induced collapse or retraction (Fig. 5E). The rate of extension after recovery was similar to that observed before collapsin application. When medium was taken from a culture in which pontine growth cones recovered after collapsin application and was applied undiluted to a fresh culture, the

medium retained collapsing activity (data not shown). The persistence of collapsin-1 activity suggests that growth cones recover because they accommodate to collapsin- 1 and not because of a reduction in collapsin-1 activity after several hours in culture.

\section{Effect of collapsin-1 on BPN and inferior olivary growth cone size}

The lamellae of BPN growth cones measured $\sim 5 \mu \mathrm{m}$ across, which is relatively small, so we were not confident about reliably scoring these growth cones as collapsed or spread as in previous studies of larger growth cones from DRG (Luo et al., 1993; Shepard et al., 1997). Instead, we measured the area of growth cones before and after the application of collapsin or control material to determine whether growth cones that stopped extending also collapsed. The measurement of growth cone areas also extended our analysis by examining a related, yet distinct aspect of collapsin action.

We measured the areas of growth cone lamellae that were imaged during the above described time-lapse analysis, both 5 min before the addition of collapsin $(20-50 \mathrm{ng} / \mathrm{ml})$ or control material and $30 \mathrm{~min}$ after these treatments (Fig. 6). Mean pontine growth cone area did not decline after $30 \mathrm{~min}$ in control material (Fig. 6A, Advanc. + Non-adv.; $n=21$ ). If only the 17 of 21 growth cones that continued to advance in control material are considered, mean area $30 \mathrm{~min}$ after treatment was $103 \%$ of the pretreatment mean, which is not a significant change. As noted above, few basilar pontine neurites were observed to stop extending or to retract after the application of control material $(n=4)$. These growth cones showed a $17 \%$ reduction in area after $30 \mathrm{~min}$ in control material, which was not significant.

In contrast to control material, collapsin-1 significantly reduced the area of basilar pontine growth cones. If all collapsin-treated growth cones are considered (Fig. 6A, Advanc. + Non-adv.; $n=$ $29)$, mean growth cone area decreased by $36 \%$, a highly significant reduction ( $p<0.001$, within group; paired $t$ test). This is also highly significant when compared with the area of growth cones treated with control material ( $p<0.001$, between groups; unpaired $t$ test); initial growth cone area was reduced to $64 \%$ in collapsin versus $99 \%$ in controls. When compared with the 17 of 21 growth cones that advanced in control material, no significant reduction in area was observed for those growth cones that continued to advance after $30 \mathrm{~min}$ in collapsin-1. The growth cones advancing in collapsin-1 (12 of 29) retained 95\% of their mean pretreatment area. However, the 17 of 29 growth cones that stopped advancing or that retracted during the $30 \mathrm{~min}$ after collapsin-1 application diminished in size to $41 \%$ of their pretreatment area. This is a significant reduction as compared with collapsin-1-treated growth cones that continued to advance.

Thus, only those pontine growth cones that did not advance in collapsin showed a significant reduction in growth cone size as compared with controls, whereas those that advanced in collapsin did not change in size as compared with growth cones that advanced in control material.

We also measured the areas of olivary growth cone lamellae observed during time-lapse experiments both $5 \mathrm{~min}$ before and 30 min after treatment with either collapsin-1 or control material. In general, inferior olivary growth cones were larger than pontine growth cones, with pooled pretreatment areas averaging $64 \%$ larger than pontine growth cones. As with pontine growth cones, however, control material had no significant effect on olivary growth cone sizes. (1) Pooled (Advanc. + Non-adv.; $n=23$ ), (2) advancing, and (3) nonadvancing control-treated growth cones 
A

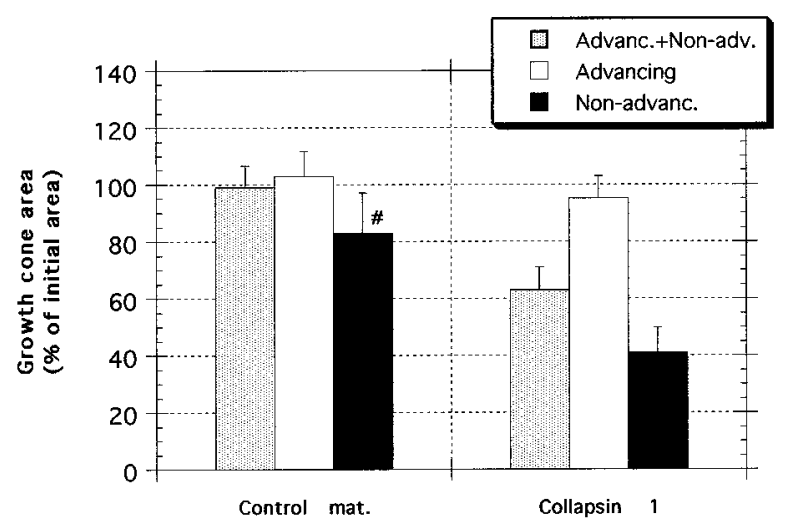

B

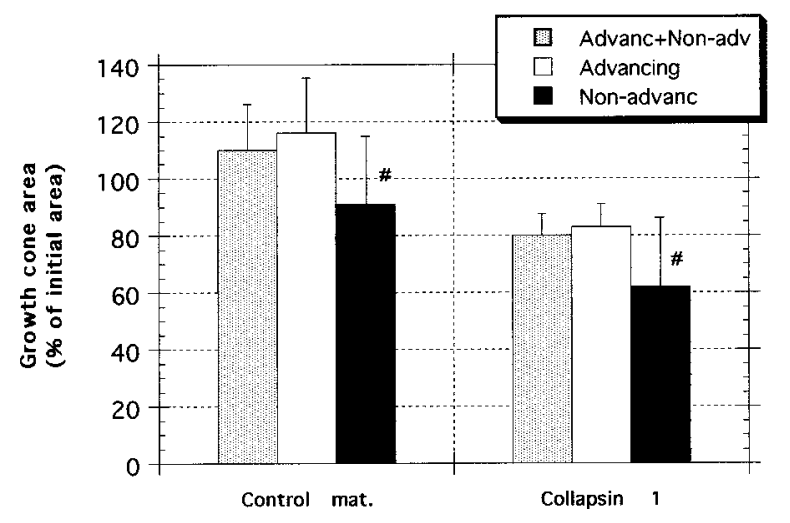

Figure 6. Growth cone areas $30 \mathrm{~min}$ after collapsin-1 or control treatment. Areas are expressed as the mean percentage of the area $5 \mathrm{~min}$ before treatment with either collapsin-1 or control material. A, Pontine mossy fibers. Control material did not significantly affect the area of growth cones from explants of basilar pontine nuclei $(n=21)$, even considering only those few growth cones that did not advance in control material $(n=4$ of 21). Collapsin-1, however, reduced growth cone areas to $64 \%$ of their pretreatment area $(n=29)$ and to $41 \%$ of the pretreatment area if only growth cones that did not advance after collapsin-1 treatment are considered $(n=12$ of 29). B, Olivary climbing fibers. Control material did not significantly affect the area of growth cones from explants of inferior olivary nuclei $(n=23)$, even considering only those few growth cones that did not advance in control material $(n=5$ of 23). Growth cone areas after collapsin- 1 treatment were $83 \%$ of their areas 5 min before collapsin treatment $(n=29)$, which was not a significant reduction as compared with areas of control material-treated growth cones, but it was a significant reduction when compared with their precollapsin areas. The areas of those few olivary growth cones $(n=4$ of 29) that did not advance in collapsin- 1 were reduced to $62 \%$ of their pretreatment value, not a significant reduction when compared with growth cones that did not advance in control material. ${ }^{*}$, Low $n(\leq 5)$.

were 116,110 , and $91 \%$ of their pretreatment areas, respectively (Fig. 6B). None of these areas was significantly different from the pretreatment values, although the number of nonadvancing control-treated growth cones was small $(n=5)$.

In contrast to basilar pontine growth cones, however, collapsin1-treated olivary growth cones were not reduced significantly in size as compared with control-treated growth cones $(p>0.05$, between groups; unpaired $t$ test). Also in contrast to pontine growth cones, there was no significant difference in area between collapsin-treated olivary growth cones that advanced and those that did not advance. Similar to pontine growth cones, those olivary growth cones that continued to advance in control mate-
Table 1. Collapsin-1 reduces the area of growth cones extending from basilar pontine nuclei explants

\begin{tabular}{lllll} 
Treatment & $\begin{array}{l}n \\
\text { (growth } \\
\text { cones) }\end{array}$ & $\begin{array}{l}\text { Mean growth } \\
\text { cone area } \\
\left(\mu \mathrm{m}^{2}\right)\end{array}$ & SEM & $\begin{array}{l}\text { Percentage of } \\
\text { medium only } \\
(\%)\end{array}$ \\
\hline Medium only & 222 & 95 & 2.9 & 100 \\
Control material 1:100 & 132 & 88 & 2.9 & 93 \\
$\begin{array}{l}\text { Control material 1:500 } \\
\text { Collapsin-1 1:500 }\end{array}$ & 61 & 92 & 4.2 & 97 \\
$\quad \begin{array}{l}\quad 50 \mathrm{ng} / \mathrm{ml}) \\
\text { Collapsin-1 1:5000 }\end{array}$ & 173 & 61 & 2.7 & $64^{* *}$ \\
$\quad(5 \mathrm{ng} / \mathrm{ml})$ & 57 & 72 & 6.6 & $76^{*}$
\end{tabular}

The area of pontine mossy fibers growth cones was measured after $40 \mathrm{~min}$ of exposure to collapsin-1, collapsin control material, or medium alone. ${ }^{* *} p<0.0001$ compared with "Medium only" or compared with "Control material 1:500."

* $p<0.02$ compared with "Medium only" or compared to "Control material 1:500."

rial or in collapsin were not significantly different in area (116 and $83 \%$ of mean initial areas, respectively). Although not significantly different in size from control-treated growth cones, olivary growth cones treated with collapsin- 1 lost $20 \%$ of their pretreatment area, which was a significant reduction $(p<0.01$, within group; paired $t$ test; Fig. $6 B ; n=29)$.

In another set of experiments we compared the effect of two concentrations of collapsin on BPN growth cone size. These experiments did not involve growth cones from time-lapse experiments so that a larger number of growth cones could be examined. After $2 \mathrm{~d}$ in culture collapsin- 1 was added to the culture medium to produce concentrations between 5 and $50 \mathrm{ng} / \mathrm{ml}$, concentrations that collapsed growth cones extending from DRG from chick (Luo et al., 1993; Shepherd et al., 1997) and mouse (see Materials and Methods). After the cultures were incubated in collapsin- 1 or control material for $40 \mathrm{~min}$, they were fixed and the growth cones were immunolabeled for actin. Collapsin-1 reduced the area subsumed by pontine growth cones by $24 \%$ at 5 $\mathrm{ng} / \mathrm{ml}$ and by $36 \%$ at $50 \mathrm{ng} / \mathrm{ml}$, both highly significant reductions when compared with growth cones similarly treated with control material (Table 1). The $36 \%$ reduction in area was the same as that observed in growth cones from our time-lapse experiments (see above). Control material had no significant effect on growth cone area, even at concentrations 50-fold greater than an effective concentration of collapsin-1.

\section{DISCUSSION}

The BPN are the major source of mossy fiber afferents of cerebellar granule cells in mammals (Brodal and Bjaalie, 1992; Altman and Bayer, 1996), whereas the inferior olivary nuclei are the source of all climbing fiber afferents of Purkinje cells. During postnatal pontocerebellar mossy fiber development the cerebellar expression of semaphorin-D in mouse was confined to Purkinje cells and nuclear neurons. At birth, sema-D was expressed mainly in medially located, parasagittally oriented bands of Purkinje cells. Between P5 and P16 sema-D was expressed by Purkinje cells in progressively more lateral regions, with banded expression no longer apparent by P16.

In vitro, collapsin-1, the sema-D chicken ortholog, caused a majority of BPN growth cones to collapse and in most cases also induced neurite retraction. Collapsin-1, however, did not inhibit the extension of inferior olivary neurites. The heterogeneity of both the expression of Purkinje cell sema-D and the response of mossy fibers to collapsin-1 suggests that, when responsive ponto- 
cerebellar mossy fibers enter the cerebellum, they may be restricted to regions lacking sema-D. Later, sema-D may contribute to the target cell specificity of these mossy fibers.

\section{Response of mossy and climbing fibers to collapsin-1}

After collapsin-1 application, $\sim 60 \%$ of BPN growth cones collapsed and arrested their extension or collapsed and then retracted. The remaining $\sim 40 \%$ of BPN growth cones continued to advance with no change in size. These growth cones were unresponsive despite exposure to 10 times the concentration of collapsin-1, which reduced the size of responsive BPN growth cones. This heterogeneity may reflect subpopulations of neurons that differ in their expression of collapsin-1 receptors. It is possible, however, that because mossy fibers in vitro sometimes can accommodate to collapsin-1, some of the fibers may have become desensitized by previous exposure to sema-D in vivo. Therefore, our finding of $\sim 60 \%$ responsive fibers is a minimum estimate. Recent results indicate that collapsin- 1 action is dependent on low levels of intracellular cGMP (Song et al., 1998). Thus it is also possible that in the present study cGMP levels in some cells were elevated, which may have contributed to the observed heterogeneity of responses.

Time-lapse microscopic analysis revealed two previously unreported effects of collapsin-1: neurite retraction and recovery of growth cones after collapse. The application of collapsin-1 to growth cones in culture medium, as in the present study, probably differs from the way in which an extending axon encounters collapsin in vivo. Nonetheless, retraction and recovery in response to collapsin- 1 are potentially significant in that these responses might allow axons contacting inappropriate targets to grow eventually to appropriate targets.

Collapsin-1 did not inhibit olivary neurite extension. In fact, collapsin-1 transiently delayed their deceleration. In addition, collapsin-1 reduced the areas of olivary growth cones in comparison with their pretreatment areas but not in comparison with control-treated growth cones. Further studies are required to evaluate the significance of the subtle effects of collapsin- 1 on olivary neurites.

\section{Semaphorin-D and the regional guidance of mossy fibers}

Purkinje cells, although not synaptic targets of mossy fibers, are crucial for the development of their projection pattern (Sotelo and Wassef, 1991). Studies of the development of pontocerebellar mossy fibers are consistent with Purkinje cell sema-D contributing to the guidance of these fibers. Although some are seen within the cerebellum as early as E16, at birth most DiI-labeled fibers from the BPN are located in the lateral portions of the cerebellum (Q. Zhang and C. Mason, unpublished observations), which lacks sema-D expression. Studies in mature cats indicate that the initially lateral projection of pontine mossy fibers is maintained into adulthood [Voogd and Glickstein (1998), their Fig. 4]. Moreover, explants of medial cerebellum from neonatal mice repelled a subset of BPN axons in collagen gel cultures (Yee et al., 1995).

The timing and pattern of mossy fiber expression of neuropilin-1, a collapse-mediating sema-D receptor (He and Tessier-Lavigne, 1997; Kitsukawa et al., 1997; Kolodkin and Ginty, 1997; Kolodkin et al., 1997; Nakamura et al., 1998), also indicate that sema-D might act as a repulsive guidance cue for pontocerebellar mossy fibers. At embryonic and early postnatal stages, pontine mossy fibers are the only cerebellar afferents with neuropilin-1 immunoreactivity, whereas cerebellar cells do not express neuropilin-1 mRNA (Kawakami et al., 1996). At early postnatal stages, cerebellar neuropilin-1 immunoreactivity, presumably on pontine mossy fibers, is highest laterally, in the developing hemispheres, with little or no immunoreactivity present medially in the developing vermis (J. Solowska and D. Baird, unpublished observations). By comparison, Purkinje cell sema-D expression at these stages is high medially, in the developing vermis, and is absent from most of the developing hemispheres.

The developmental regulation of sema-D and/or its graded distribution also might contribute to the establishment of pontocerebellar topography. Comparing the results of retrograde labeling studies (Burne et al., 1978; Eisenman, 1981; Nikundiwe et al., 1994) with the birth dates of BPN neurons (Altman and Bayer, 1987, 1996) suggests that early born BPN neurons project to more medial regions of the hemispheres than later born BPN neurons. Sema-D expression broadens in the developing hemispheres when mossy fibers are synapsing on granule cells (Larramendi, 1969; Altman, 1972; Hámori and Somogyi, 1983; Altman and Bayer, 1996). Therefore, the expansion of sema-D expression along the cerebellar mediolateral axis might restrict laterdeveloping mossy fibers to more lateral regions of the hemispheres.

During the first $10 \mathrm{~d}$ of postnatal development of the lateral cerebellar hemispheres, only Purkinje cells of the floccular lobule of the inferior lobe expressed sema-D. The major mossy fiber input to the flocculus is from the vestibular nuclei (Ruigrok and Cella, 1995), although there are a few projections from the pontine nuclei (Blanks et al., 1983). Sema-D might prevent responsive mossy fibers from entering the flocculus. This possibility is suggested by the low level of neuropilin-1 immunoreactivity present in the developing flocculus at early postnatal stages, with higher levels in adjacent lobules (J. Solowska and D. Baird, unpublished observations).

In addition to Purkinje cells, sema-D also is expressed in some cells of the cerebellar nuclei. A subset of pontine neurons project to specific neurons of the cerebellar nuclei as collateral branches of mossy fibers terminating in the cerebellar cortex (Shinoda et al., 1992; Mihailoff, 1993, 1994). Sema-D expression in the cerebellar nuclei might contribute to the guidance of mossy fibers by repelling sema-D-responsive mossy fibers from inappropriate nuclear targets while permitting only unresponsive mossy fibers to project. The role of sema-D in guiding mossy fibers, both in nuclei and cortex, however, can be assessed better after characterization of the projection patterns of the collapsin-1/sema-D-responsive mossy fibers.

Catalano et al. (1998) did not find defects in the CNS of sema-D knock-out mice, including pontocerebellar mossy fibers. The failure to detect a mossy fiber phenotype may have been caused by several factors. First, in our in vitro studies $60 \%$ of BPN mossy fibers responded to collapsin-1/sema-D. Unresponsive fibers may have appeared normal in the mutant. Second, BPN mossy fibers are intermingled with mossy fibers from other sources, including those from elsewhere in the pons, which also might obscure a phenotype involving a misprojection of only the sema-D-responsive BPN mossy fibers. Finally, a newly discovered semaphorin, K1, recently was shown to be expressed in Purkinje cells in postnatal mice (Xu et al., 1998). Sema-K1 or other uncharacterized Purkinje cell semaphorins also might repel mossy fibers and be unaffected by mutations of the sema-D gene. 


\section{Semaphorin-D as a determinant of target cell specificity}

Climbing fibers, which arise from the inferior olivary nuclei, primarily synapse with Purkinje cells and not with granule cells, whereas mossy fibers primarily synapse with granule neurons and not with Purkinje cells. Sema-D, which is expressed only by Purkinje cells in the cerebellar cortex, may contribute to the differing target cell specificity and laminar projections of climbing and mossy fibers, because collapsin-1 did not inhibit the growth of inferior olivary fibers but arrested the growth of pontocerebellar fibers for prolonged periods or caused retraction of these fibers.

Mason and Gregory (1984) described inappropriate branches of immature mossy fibers that transiently innervate Purkinje cells but that retract by day 30 in the mouse. Sema-D could be involved in the development of these "combination" fibers, either by permitting sema-D-insensitive mossy fibers to contact Purkinje cells or by contributing to the retraction of combination fibers from sema-D-responsive fibers.

In summary, the response of mossy fibers to collapsin-1/semaphorin-III/D and its changing distribution over the cerebellar cortex suggest that this protein may shape pontine mossy fiber innervation in at least two ways. First, the restricted distribution of sema-D may help to repel responsive pontine mossy fibers from inappropriate target regions. This action of sema-D is consistent with its proposed function as a repulsive guidance cue in the developing spinal cord and peripheral nervous system and with mossy fiber development and neuropilin-1 expression. Second, as Purkinje cells throughout the cerebellum express sema-D during mossy fiber synaptogenesis, it may serve to prevent pontine mossy fibers from terminating on an inappropriate target neuron.

\section{REFERENCES}

Adams RH, Betz H, Püschel AW (1996) A novel class of murine semaphorins with homology to thrombospondin is differentially expressed during early embryogenesis. Mech Dev 57:33-45.

Altman J (1972) Postnatal development of the cerebellar cortex in the rat. III. Maturation of the components of the granule layer. J Comp Neurol 145:465-514.

Altman J, Bayer SA (1987) Development of the precerebellar nuclei in the rat. IV. The anterior precerebellar extramural migratory stream and the nucleus reticularis tegmenti pontis and the basal pontine gray. J Comp Neurol 257:529-552.

Altman J, Bayer SA (1996) Development of the cerebellar system: in relation to its evolution, structure and functions. New York: CRC.

Azizi SA, Mihailoff GA, Burne RA, Woodward DJ (1981) The pontocerebellar system in the rat: an HRP study. I. Posterior vermis. J Comp Neurol 197:543-558.

Baird DH, Baptista CA, Wang L-C, Mason CA (1992a) Specificity of a target neuron-derived stop signal for afferent axonal growth. J Neurobiol 23:579-591.

Baird DH, Hatten ME, Mason CA (1992b) Cerebellar target neurons provide a stop signal for afferent neurite extension. J Neurosci 12:619-634.

Baird DH, Hatten ME, Heintz N, Mason CA (1994) Micro-methods for analyzing axon-target interactions in vitro. NeuroProtocols: Comp Methods Neurosci 4:106-115.

Baird DH, Trenkner E, Mason CA (1996) Arrest of afferent axon extension by target neurons in vitro is regulated by the NMDA receptor. J Neurosci 16:2642-2648.

Baird DH, Rabacchi SA, Solowska JM, Kruk B (1997) Regulation of pontocerebellar mossy fiber extension by BDNF and collapsin-1/semaphorin-III/D. Exp Neurol 151:151.

Baker GE, Reese BE (1993) Using confocal laser scanning microscopy to investigate the organization and development of neuronal projections labeled with DiI. Methods Cell Biol 38:325-344.

Baynard MD, Rabacchi SA, Carney C, Hoffman JR, Kruk B, Baird DH (1997) BDNF regulates cerebellar mossy fiber extension and fasciculation. Soc Neurosci Abstr 23:136.9.
Behar O, Golden JA, Mashimo H, Schoen FJ, Fishman MC (1996) Semaphorin III is needed for normal patterning of growth of nerves, bones, and heart. Nature 383:525-528.

Blanks RHI, Precht W, Torigoe Y (1983) Afferent projections to the cerebellar flocculus in the pigmented rat demonstrated by retrograde transport of horseradish peroxidase. Exp Brain Res 52:293-306.

Braissant O, Wahli W (1998) A simplified in situ hybridization protocol using non-radioactively labeled probes to detect abundant and rare mRNAs on tissue sections. Biochemica 1:10-16.

Brodal P, Bjaalie JG (1992) Organization of the pontine nuclei. Neurosci Res 13:83-118.

Brodal P, Mihailoff G, Border B, Ottersen OP, Storm-Mathisen J (1988) GABA-containing neurons in the pontine nuclei of rat, cat and monkey. An immunocytochemical study. Neuroscience 25:27-45.

Burne RA, Eriksson MA, Saint-Cyr JA, Woodward DJ (1978) The organization of the pontine projection to lateral cerebellar areas in the rat: dual zones in the pons. Brain Res 139:340-347.

Catalano SM, Messersmith EK, Goodman CS, Shatz CJ, Chédotal A (1998) Many major CNS axon projections develop normally in the absence of semaphorin III. Mol Cell Neurosci 11:173-182.

Chédotal A, Pourquié O, Ezan F, San Clemente H, Sotelo C (1996) $\mathrm{BEN}$ as a presumptive target recognition molecule during the development of the olivocerebellar system. J Neurosci 16:3296-3310.

Chen H, Chédotal A, He Z, Goodman CS (1997) Neuropilin-2, a novel member of the neuropilin family, is a high affinity receptor for the semaphorins E and sema IV but not sema III. Neuron 19:547-559.

Eisenman LM (1980) Pontocerebellar projections to the paraflocculus in the rat. Brain Res 188:550-554.

Eisenman LM (1981) Pontocerebellar projections to the pyramis and copula pyramidis in the rat: evidence for a mediolateral topography. J Comp Neurol 199:77-86.

Eisenman LM, Noback CR (1980) The ponto-cerebellar projection in the rat: differential projections to sublobules of the uvula. Exp Brain Res 38:11-17.

Giger RJ, Wolfer DP, de Wit GMJ, Verhaagen J (1996) Anatomy of rat semaphorin III/collapsin-1 mRNA expression and relationship to developing nerve tracts during embryogenesis. J Comp Neurol 3:378-392.

Goldman-Wohl D, Chan E, Baird D, Heintz N (1994) KV3.3b: a novel Shaw-type potassium channel expressed in terminally differentiated cerebellar Purkinje cells and deep cerebellar nuclei. J Neurosci 14:511-522.

Hámori J, Somogyi J (1983) Differentiation of cerebellar mossy fiber synapses in the rat: a quantitative electron microscope study. J Comp Neurol 220:365-377.

He Z, Tessier-Lavigne M (1997) Neuropilin is receptor for the axonal chemorepellent semaphorin III. Cell 90:739-751.

Inagaki S, Furuyama T, Iwahashi Y (1995) Identification of a member of mouse semaphorin family. FEBS Lett 370:269-272.

Kawakami A, Kitsukawa T, Takagi S, Fujisawa H (1996) Developmentally regulated expression of a cell surface protein, neuropilin, in the mouse nervous system. J Neurobiol 29:1-17.

Kitsukawa T, Shimizu M, Sanbo M, Hirata T, Taniguchi M, Bekku Y, Yagi T, Fujisawa H (1997) Neuropilin-semaphorin III/D-mediated chemorepulsive signals play a crucial role in peripheral nerve projection in mice. Neuron 19:995-1005.

Kolodkin AL (1996) Semaphorins-mediators of repulsive growth cone guidance. Trends Cell Biol 6:15-22.

Kolodkin AL, Ginty DD (1997) Steering clear of semaphorins: neuropilins sound the retreat. Neuron 19:1159-1162.

Kolodkin AL, Matthes DJ, O'Connor TP, Patel NH, Bentley D, Goodman CS (1992) Fasciclin IV: sequence, expression and function during growth cone guidance in the grasshopper embryo. Neuron 9:831-845.

Kolodkin AL, Matthes DJ, Goodman CS (1993) The semaphorin genes encode a family of transmembrane and secreted growth cone guidance molecules. Cell 75:1389-1399.

Kolodkin AL, Levengood DV, Rowe EG, Tai Y-T, Giger RJ, Ginty DD (1997) Neuropilin is a semaphorin III receptor. Cell 90:753-762.

Larramendi LMH (1969) Analysis of synaptogenesis in the cerebellum of the mouse. In: Proceedings of the first international symposium of the Institute for Biomedical Research. Neurobiology of cerebellar evolution and development (Llinás R, ed), pp 803-843. Chicago: American Medical Association. 
Luo Y, Raible D, Raper JA (1993) Collapsin: a protein in brain that induces the collapse and paralysis of neuronal growth cones. Cell 75:217-227.

Luo Y, Shepherd I, Li J, Renzi MJ, Chang S, Raper JA (1995) A family of molecules related to collapsin in the embryonic chick nervous. Neuron 14:1131-1140.

Mason CA, Gregory E (1984) Postnatal maturation of cerebellar mossy and climbing fibers: transient expression of dual features on single axons. J Neurosci 4:1715-1735.

Mason CA, Morrison ME, Ward MS, Zhang Q, Baird DH (1997) Axontarget interactions in the developing cerebellum. Perspect Dev Neurobiol 5:69-82.

Matthes DJ, Sink HS, Kolodkin AL, Goodman CS (1995) Semaphorin II can function as a selective inhibitor of specific synaptic arborizations. Cell 81:631-639.

Messersmith EK, Leonardo ED, Shatz CJ, Tessier-Lavigne M, Goodman CS, Kolodkin AL (1995) Semaphorin III can function as a selective chemorepellent to pattern sensory projections in the spinal cord. Neuron 14:949-959.

Mihailoff GA (1993) Cerebellar nuclear projections from the basilar pontine nuclei and nucleus reticularis tegmenti pontis as demonstrated with PHA-L tracing in the rat. J Comp Neurol 330:130-146.

Mihailoff GA (1994) Identification of pontocerebellar axon collateral synaptic boutons in the rat cerebellar nuclei. Brain Res 648:313-318.

Mihailoff GA, Burne RA, Azizi SA, Norell G, Woodward DJ (1981) The pontocerebellar system in the rat: an HRP study. II. Hemispheral components. J Comp Neurol 197:559-577.

Nakamura F, Tanaka M, Takahashi T, Kalb RG, Strittmatter SM (1998) Neuropilin-1 extracellular domains mediate semaphorin-D/III-induced growth cone collapse. Neuron 21:1093-1100.

Nikundiwe AM, Bjaalie JG, Brodal P (1994) Lamellar organization of pontocerebellar neuronal populations. A multi-tracer and 3-D computer reconstruction study in the cat. Eur J Neurosci 6:173-186.

Palay SL, Chan-Palay V (1974) Cerebellar cortex: cytology and organization. New York: Springer.

Püschel AW, Adams RH, Betz H (1995) Murine semaphorin D/collapsin is a member of a diverse gene family and creates domains inhibitory for axonal extension. Neuron 14:941-948.

Raper JA, Kapfhammer JP (1990) The enrichment of a neuronal growth cone collapsing activity from embryonic chick brain. Neuron $4: 21-29$.

Ruigrok TJH, Cella F (1995) Precerebellar nuclei and red nucleus. In: The rat nervous system, 2nd Ed (Paxinos G, ed), pp 277-307. New York: Academic.

Shepherd I, Luo Y, Raper JA, Chang S (1996) The distribution of collapsin-1 mRNA in the developing chick nervous system. Dev Biol 173:185-199.

Shepherd IT, Luo Y, Lefcort F, Reichardt LF, Raper JA (1997) A sensory axon repellent secreted from ventral spinal cord explants is neutralized by antibodies raised against collapsin-1. Development 124:1377-1385.

Shinoda Y, Sugiuchi Y, Futami T, Izawa R (1992) Axon collaterals of mossy fibers from the pontine nucleus in the cerebellar dentate nucleus. J Neurophysiol 67:547-560.

Song H-j, Ming G-1, He Z, Lehmann M, McKerracher L, Tessier-Lavigne M, Poo M-m (1998) Conversion of neuronal growth cone responses from repulsion to attraction by cyclic nucleotides. Science 281:15151518.

Sotelo C, Wassef M (1991) Cerebellar development: afferent organization and Purkinje cell heterogeneity. Philos Trans R Soc Lond [Biol] 331:307-313.

Takahashi T, Nakamura F, Jin Z, Kalb RG, Strittmatter SM (1998) Semaphorins A and E act as antagonists of neuropilin-1 receptors and agonists of neuropilin-2 receptors. Nat Neurosci 1:487-493.

Taniguchi M, Yuasa S, Fujisawa H, Naruse I, Saga S, Mishina M, Yagi T (1997) Disruption of semaphorin III/D gene causes severe abnormality in peripheral nerve projection. Neuron 19:519-530.

Tessier-Lavigne M, Goodman CS (1996) The molecular biology of axon guidance. Science 274:1123-1133.

Varela-Echavarria A, Tucker A, Püschel AW, Guthrie S (1997) Motor axon subpopulations respond differentially to the chemorepellents netrin-1 and semaphorin-D. Neuron 18:193-207.

Voogd J, Glickstein M (1998) The anatomy of the cerebellum. Trends Neurosci 21:370-375.

Wassef M, Chédotal A, Cholley B, Thomasset M, Heizmann CW, Sotelo C (1992) Development of the olivocerebellar projection in the rat. I. Transient biochemical compartmentation of the inferior olive. J Comp Neurol 323:519-536.

Wong JTW, Yu WTC, O'Connor TP (1997) Transmembrane grasshopper semaphorin I promotes axon outgrowth in vivo. Development 124: 3597-3609.

Wright DE, White FA, Gerfen RW, Silos-Santiago I, Snider WD (1995) The guidance molecule semaphorin III is expressed in regions of spinal cord and periphery avoided by growing sensory axons. J Comp Neurol 361:321-333.

Xu X, Ng S, Wu Z-L, Nguyen D, Homburger S, Seidel-Dugan C, Ebens A, Luo Y (1998) Human semaphorin K1 is glycosylphosphatidylinositol-linked and defines a new subfamily of viral-related semaphorins. J Biol Chem 273:22428-22434.

Yee KT, Simon HH, O'Leary DDM (1995) Chemorepulsive activity from the cerebellum inhibits neurite outgrowth from the basilar pons. Soc Neurosci Abstr 21:292.

Yu HH, Araj HH, Ralls SA, Kolodkin AL (1998) The transmembrane semaphorin sema I is required in Drosophila for embryonic motor and CNS axon guidance. Neuron 2:207-220.

Zhou L, White FA, Lentz SI, Wright DE, Fisher DA, Snider WD (1997) Cloning and expression of a novel murine semaphorin with structural similarity to insect semaphorin I. Mol Cell Neurosci 9:26-41. 